\title{
Osmoregulation Pattern of Fingerling Vanname Shrimp (Litopenaeus vannamei) Rearing in Three Molt Stage Iso-Osmotic Media
}

\author{
Sutrisno Anggoro*, Djoko Suprapto and Frida Purwanti \\ Fisheries Department, Faculty of Fisheries and Marine Science, Diponegoro University \\ J. Prof. H. Soedarto, S.H. Tembalang Semarang, 50275 Indonesia \\ E-mail: sutrisno.anggoro@yahoo.co.id/sutrisnoanggoro52@gmail.com
}

\begin{abstract}
Vanname shrimp (Litopenaeus vannamei) is one of euryhaline Crustacean that able to adapt to a wider range of salinities. The need of suitable media for a given size and molting stage of shrimp is a key factor of the success of shrimp culture. In order to ensure the success of fingerling Vanname shrimp (FVS) rearing, it is indispensable to provide suitable osmotic media for the molting process. This research was aimed to examine and determine isoosmotic media that complies with physiological process of FVS. The research was done in laboratory scale with Completely Randomized Design. FVS was acclimated to three salinities level i.e. 15-16 \%o as the postmolt isosmotic media, 25-26 \%o as the intermolt isosmotic media, and 29-30 \%o as the premolt and molt isosmotic media with three replications. The result showed that in the media of 25-26\%, the osmotic work revealed the minimal level and it enhanced the growth rate without changing the amino acids composition in the shrimp body tissue.
\end{abstract}

Key words: molting; osmo-effector; osmoregulation

\section{Introduction}

Vanname shrimp is widely known as a euryhaline osmoregulator. As experienced by other osmoregulating crustaceans, survival, metamorphic development and growth of FVS is influenced by osmotic balance between body fluids and ambient water media (Che Mat, 1987; Ferraris et al., 1987). In breeding and rearing activities, the osmotic balance is mainly affected by salinity of the media.

The effect of salinity (as a masking factor) on molting and growth of shrimp may occur directly or indirectly. In most of the euryhaline animals, the direct effect of salinity works through its osmotic Influence on the osmoregulation, food digestion and absorption by the animal (Anggoro and Nakamura, 2009). In the case in a wider range of salinities, may result in mass mortality of Scallop embryo and larvae caused by disturbance of osmolarity balance (Sahri et al, 2014); this also because will affect the osmoregulation and bioenergetics of the aquatic organism (Capuzzo, 1982).

In growing post larvae and FVS, ideal salinity that close to isosmotic ranges is required (Ferraris et al., 1987). In fact, there are three isoosmotic references, namely postmolt isosmotic (20\%), intermolt isosmotic (25\%), and premolt/molt isosmotic (30\%) (Anggoro et al., 2008). It is not yet well understood, from these three references which one is the most suitable to the shrimp to minimize the osmotic work and enhance the growth rate without affecting the composition of organic osmo-effector (free amino acids) in the hemolymph of shrimp.

This research was aimed to investigate and find out the effect of osmotic salinity level media on osmotic work, Na-K-ATPase enzyme activity, and composition of organic osmo-effector in FVS. The end goal of this research was to establish the ideal salinity suitable for Vanname shrimp culture especially from larvae until fingerling stage.

\section{Materials and Methods}

Juveniles vanname shrimp with initial weight of $4.55 \pm 0.03$ g were used. Water media was prepared by mixing seawater and fresh water to make saline water at the desired salinities. Getting the desired salinity water, dilution was done by adding pre-filtered deionized fresh water into testing chambers.

Tested shrimps were fed with commercial feed obtained from local market with the following composition: protein (40.41\%), lipid (5\%), fiber (3\%), and water (11\%). Feed was given at the amount of $8 \%$ of the average weight of tested animal in the morning (4 am), noon (12 am), afternoon (5 pm), and night (11 $\mathrm{pm}$ ). Uneaten feeds were cleared up (siphoned) every 2 hours prior to the next feeding. 
Three concrete tanks measuring $2.55 \mathrm{~m} \mathrm{x}$ $1.50 \mathrm{~m} \times 1.10 \mathrm{~m}$ were used. Each contained of $2 \mathrm{~m}^{3}$ of water media and partitioned with nylon net and silk screening into three compartments. Each compartment was considered as one replicate and filled with one shrimp. The isolation of each tested shrimp was meant to avoid cannibalism and to make easier observation. Each tank was aired to maintain the dissolved oxygen remain high.

The research was conducted by laboratory experimental method. The experimental design applied was completely randomized design with three treatments and three replications. The main treatment was different salinity levels which consisted of: Treatment A: media with salinity of $20-21 \%$ o (578.73 mOsm. $\mathrm{L}^{-1} \mathrm{H}_{2} \mathrm{O}$ ), representing the postmolt isosmotic for FVS; Treatment $\mathrm{B}$ : media with salinity of $25-26 \%$ o (728.22 mOsmol. $\mathrm{L}^{-1} \mathrm{H}_{2} \mathrm{O}$ ), representing the intermolt isosmotic for FVS; and Treatment C: media with salinity of $29-30 \%$ o $\left(875.46\right.$ mOm. L-1 $\left.\mathrm{H}_{2} \mathrm{O}\right)$, representing the molt isosmotic for FVS.

The ambient temperature was maintained at Ideal level suitable for the growth of FVS, which was $30-31^{\circ} \mathrm{C}$, with thermo regulator Riena.HP. Maintaining temperature stability and to reduce evaporation, each chamber was covered by dark-blue plastic. The variables measured were: (a) hemolymph osmolarity and osmotic work level, (b) the activity of Na-K-ATPase enzyme, (c) concentration of organic osmo-effector (amino acids composition) in shrimp hemolymph. Variable (a) was measured every 15 days following the method of Ferraris et al. (1987), Anggoro and Muryati (2006). Shrimp hemolymph was taken as much as $0.05 \mathrm{ml}$ from pericardium cavity with 23G syringe and osmolarity was measured with Automatic Osmometer Roebling. The Na.K.ATPase enzyme activity was also measured following Anggoro and Nakamura (2009). The measurement of free amino acids composition was conducted following Dalla Via (1986) as follows: (a) Sample collection and amino acids determination was carried out at the beginning and the end of experiment. (b) Prior to free amino acids analysis shrimp was fasted for 48 hours to avoid amino acids addition from food. (c) Sample for free amino acids analysis was obtained by extracting shrimp body fluid, added by $7 \%$ perchloric acid and $1.5 \mathrm{ml}$ norleucine solution. (d) Samples were homogenized by centrifuge for 20 minutes at 2000 rpm. (e) Supernatant was neutralized with $5 \mathrm{M} \mathrm{KOH}$ (to achieve $\mathrm{pH} 5-7$ ), and then vaccumed until dry and diluted with $0.2 \mathrm{M}$ lithium citrate buffer ( $\mathrm{pH}$ 2.2). Solution was injected into FAA analyzer (Labotron Liquimat III FAA Analyzer, Geretsried, FRG) to determine amino acids content and composition of the sample. Analysis of FAA content and composition in Penaeids should be focused on FAA species that play an important role as osmo-effector, namely: glycine, praline, alanine, taurine, ornithine, glutamate, arginine and lysine (Dalla Via, 1986).

Osmotic response and FAA composition relating to molting phase, Na-K.ATPase activity, and osmotic work of shrimp in isosmotic media (molt, postmolt and intermolt) were analyzed with analysis of variance of orthogonally polynomial contrast model. Water quality parameters, i.e. salinity, osmolarity, temperature, and dissolved oxygen (DO) were measured daily and monitored periodically.

\section{Results and Discussion}

\section{Osmotic regulation}

Osmotic Work Level (OWL) is a respond or work load performed by Vanname shrimp in order to maintain the balance between osmolarity of internal body fluid and that of ambient media. The magnitude of OWL commonly is in line with the activity of Na-KATPase enzyme (Che Mat, 1987). The OWL of FVS at different molting phases during the experiment could be seen in Table 1.

Vanname shrimp is a euryhaline species, which able to endure wide range of salinity media through osmoregulation mechanism. Nevertheless, the osmotic effect of water media on osmoregulation of shrimp still has significant impact on their survival and vitality (Anggoro, 2002). While hemolymph osmolarity of FVS always moves and changes according to the salinity media and molting phase. The change is induced by osmoregulation mechanism and molting of the shrimp (Ferraris et al., 1987; Anggoro and Setiarto, 2001). It was found that hemolymph osmolarity of FVS varied with different molting phases (Table 1.). At premolt/molt phase, hemolymph osmolarity is higher than that at intermolt and postmolt.

The changes in osmolarity are closely associated with osmoregulation mechanism and molting process. At premolt phase, hemolymph osmolarity is high, which is among other caused by mobilization and accumulation of nutrient into hemolymph and hepato-pancreas, and early formation of new integument that is indicated by

Table 1. Osmotic Work Level of FVS during the Experiment (mOsm. $\mathrm{I}^{-1} \mathrm{H}_{2} \mathrm{O}$ )

\begin{tabular}{|c|c|c|c|}
\hline $\begin{array}{l}\text { Molting } \\
\text { Phase }\end{array}$ & $20-21 \%$ & $25-26 \%$ & $29-30 \%$ \\
\hline Pre molt & $275,95 \pm 0,02$ & $130,78 \pm 0,02$ & $15,44 \pm 0,01$ \\
\hline Molt & $271,52 \pm 0,02$ & $124,83 \pm 0,02$ & $24,33 \pm 0,01$ \\
\hline Postmolt & $0,75 \pm 0,01$ & $137,89 \pm 0,02$ & $285,34 \pm 0,02$ \\
\hline Intermolt & $94,36 \pm 0,02$ & $47,60 \pm 0,01$ & $19548 \pm 0,02$ \\
\hline
\end{tabular}


Table 2. Na-K.ATPase Activity of FVS in Different Salinities

\begin{tabular}{ccc}
\hline Salinity (\%o) & Replicate & Na-K.ATPase $($ mmolpi.g-1) \\
\hline $20-21$ & 1 & 7,42 \\
& 2 & 7,40 \\
& 3 & 7.46 \\
\hline mean & & $7,43 \pm 0,02$ \\
\hline $25-26$ & 1 & 3,76 \\
& 2 & 3,68 \\
& 3 & 3,75 \\
\hline mean & & $3,73 \pm 0,03$ \\
\hline $29-30$ & 1 & 6,85 \\
& 2 & 6,74 \\
& 3 & 6,77 \\
\hline mean & & $6,79 \pm 0,04$ \\
\hline
\end{tabular}

dissolution of organic and inorganic matter of old integument into hemolymph (extracellular fluid). This is consistent with other researchers (Ferraris et al., 1987; Anggoro and Nakamura, 2009; Anggoro and Subandiyono, 2012) who suggested that at premolt phase there is mobilization and accumulation of inorganic nutrient, such as $\mathrm{Ca}, \mathrm{P}$ and organic nutrient and inorganic from old integument into shrimp hemolymph. While in molt phase, water absorption and mineralization process result in the thickening of extracellular fluid so that it is hyperosmotic against intracellular fluid (Anggoro and Nakamura, 2009; Anggoro and Subandiyono, 2012).

During postmolt and intermolt phases, hemolymph osmolarlty is lower than that at premolt/molt phase. This is because during postmolt and intermolt phases, osmotic pressure of intracellular fluid begins to approach the level of extracellular one and it will stop when the isosmotic condition (the balance between the two) has been achieved. This isosmotic condition is an ideal osmotic pressure for the growth of shrimp, which is indicated by the lower rate of OWL and Na-K-ATPase enzyme activity. The result of previous experiment by Brooks and Mills (2006), Duncan et al. (2009) and Anggoro and Subandiyono (2012) gave the same evidence, the activity of Na-K-ATPase in hyper and hypo-osmotic medium is stronger than that in isosmotic medium. During premolt phase, however, due to excessive water absorption, the osmolarity of extracellular fluid is the lowest compared to other molting phases (Table 1.). Isosmotic or close to isosmotic condition was achieved in media with a salinity of $25-26 \%$ (isosmotic of intermolt phase). This was indicated by the least difference between media osmolarity and hemolymph osmolarity of FVS. This low OWL was thought to be caused by two actors (Che Mat, 1987; Anggoro and Setiarto, 2001; Anggoro and Nakamura, 2009; Anggoro and Subandiyono, 2012), i.e.: (1) Activity of Na.K.ATPase enzyme was at minimum; (2)
Active transport of ions and osmoeffector exchange was at the lowest level.

Robust external media in intermolt phase is an optimum condition for enzym activity, so that, protein synthesis and growth are at maximum rate. This is consistent with earlier finding by Ferraris et al. (1987), Dalla Via (1986), Anggoro and Subandiyono (2012) that total protein content and free amino acids are the highest in the intermolt phase.

\section{Organic osmoeffector}

The level of organic osmo-effector in the intracellular fluids is governed by amino acids content therein (Dalla Via, 1986). Those free amino acids determine flavour and smell of the shrimp. Free amino acids in the hemolymph of FVS consist of glycine, taurine, proline, arginine, alanine, glutamate, histidine, and ornithine (Table 3.). From the table it is obvious that when the salinity gets higher, the content of glysine, taurine, proline and alanine are also higher. Whereas other free amino acids, such as arginine, glutamate, histidine; and ornithine were relatively stable. In other words, salinity significantly affects the content of glycine, taurine, proline, alanine, but it does not affect the level of arginine, glutamate, histidine and ornithine in the hemolymph. This is consistent with Dalla Via (1986) and Anggoro Subandiyono (2012) finding that major free amino acids content (proline, glycine and taurine) increased in higher salinity (hyperosmotic) and decreased in lower salinity (hyposmotic). The change in composition and content of free amino acids is related to osmotic mechanism performed by shrimp (Anggoro and Nakamura, 2009; Anggoro and Subandiyono, 2012). Considering that the composition and content of these major free amino acids affect taste and flavor of shrimp meat (Dalla Via, 1986; Spanopoulos et al., 2005), it is necessary to maintain suitable salinity level to prevent excessive hyposmotic stress, which will change the specific taste and flavour of marine shrimp.

Table 3. Organic Osmoeffector Content (Free Amino Acids) of Hemolymph of FVS ( $m$ mol.g-1 dry weight)

\begin{tabular}{|c|c|c|c|}
\hline \multirow{2}{*}{ Free Amino Acids } & \multicolumn{3}{|c|}{ Salinity } \\
\hline & $20-21 \%$ 。 & $25-26 \%$ & $29-30 \%$ \\
\hline Glycine & 250,30 & 300,50 & 350,80 \\
\hline Taurine & 137,80 & 150,50 & 156,78 \\
\hline Praline & 97,50 & $99, I S$ & 101,22 \\
\hline Arginine & 97,99 & 98,08 & 98,65 \\
\hline Alanine & 49,68 & 56,68 & 59,96 \\
\hline Glutamate & 9,77 & $9, .79$ & 9,79 \\
\hline Histidine & 6,93 & 7,01 & 7,04 \\
\hline Omitrine & 2,16 & 2,20 & 2,21 \\
\hline
\end{tabular}




\section{Conclusion}

The use of isosmotic media (25-26\%, equal to $\left.726.22 \mathrm{mOsm} . \mathrm{L}^{-1} \mathrm{H}, \mathrm{O}\right)$ resulted in a minimum OWL by shrimp and maintained the ideal level of composition of osmoeffector, and also optimized the growth of FVS. While for rearing, it is recommended to use a water media close to intermolt and isomolt level, even though during molting the shrimp needs a media with intermolt hyperosmotic level (around 30\%o). In the case of maintaining the specific taste and flavour of marine shrimp, it is necessary to control culture media in order to prevent extreme hyperosmotic stress that will change the content and composition of organic osmoeffector (free amino acids) in the shrimp body.

\section{Acknowledgement}

The authors gratefully acknowledge the valuable advice and kind assistance of Dean Faculty of Fisheries and Marine Science and Director of "Gatot Rahardjo Joenoes" Coastal Laboratory, Diponegoro University. This research was supported by Undip PNPB research grant in year 2015/2016, SPK No. 2182/UN7.3.10/PG/2015 and SK Rektor ub. Dekan FPIK Undip No. 51/UN7.3.10/HK/2015-funded by the Faculty of Fisheries and Marine Science, Diponegoro University.

\section{References}

Anggoro, S. 2002. Efek Osmotik Tingkat Salinitas Media terhadap Daya Pijah dan Kemampuan Osmoregulasi Penaeus monodon Fabr. IImu Kelautan. 4(15):110-116.

Anggoro, S. \& Setiarto, A. 2001. Osmotic Response of Tiger Shrimp (Penaeus monodon) Broodstock in Various Molting Stages. J. Coastal Development. 2(1): 245-252.

Anggoro, S. \& Nakamura, K. 2009. Osmotic Response and Feeding Pattern of Kuruma Prawn (Penaeus japonicus) at Various Molting Stages. Research Report, Lab. Propagating Physiol., Fisheries Fac., Kagoshima University. Kagoshima.

Anggoro, S., Subandiyono \& Supratno, T. 2008. Laporan Riset Insentif Teknik Domestikasi Udang Liar Asal Segara Anakan. LPPM Undip, Semarang.

Anggoro, S. \& Muryati. 2006. Respon Osmotic Juvenil dan Udang Windu (Penaeus monodon) pada Berbagai Tahapan Molting dan Salinitas yang
Berbeda. Buletin Penelitian dan Pengembangan Industri. 2(1):59-64.

Anggoro, S. \& Subandiyono. 2012. Osmotic responses of Segara Anakan fine shrimp (Metapenaeus elegans) adult in various salinity and molting stages. J. Coastal Development. 15(3): 310314.

Brooks, S.J. \& Mills, C.L. 2006. Gill Na-K-ATPase in a Series of Hyper-Regulating Gammarid Amphipods, Enzyme Characterisation and The Effects of Salinity Acclimation. Comparative Biochemistry and Physiology Part A, 144: 24-32.

Che Mat, R. 1987. Kajian Ekofisiologi dan Biokimia Macrobrachium rosenbergii dan hubungannya dengan Akuakultur. In: S. Sarmani (Ed.), Prosiding FSG, Univ. Kebangsaan Malaysia, Sangi, pp.260.273.

Capuzzo, J.M. 1982. Crustacean Bioenergetics: the Role of Environmental Variables and Dietary Levels of Macronutrients on Energetic Efficiencies. Spec. Publ. WId Maricult. Soc. 2: 7186.

Dalla Via, G.J. 1986. Salinity Responses of The Juvenile Penaeid Shrimp Penaeus japonicus: II. Free amino acids. Aquaculture. 55(4): 307-316. doi: doi : 10.1016/0044-8486(86)90 171-7

Duncan, W.P., Coasta, O.T.F., Araujo, M.L.G. \& Fernandes, M.N. 2009. Ionic regulation and $\mathrm{Na}^{+}-$ $\mathrm{K}^{+}$-ATPase activity in gills and kidney of the freshwater stingray Paratrygon aiereba living in white and blackwaters in the Amazon Basin. J. Fish Biology. 74: 956-960. doi: 10.1111/j.10958649.2008.02156.x

Ferraris, R.P., Estepa, F.D.P., De Jesus, E.G. \& Ladja, J.M. 1987. Osmoregulation in Penaeus monodon Effects of Molting and External Salinity, In J. L. Maclean et al (Eds.). The First Asean Fisheries Forum, AFS, Manila, pp 637-640.

Sahri, A., Anggoro, S. \& Suprijanto, J. 2014. Habitat Suitability Modelling of Asian-Moon Scallop (Amusium pleuronectes) in Brebes District Waters, Central Java, Indonesia. Int. J. Mar. Sci. 4(61): 1-13.

Spanopoulos-Hernandez, M., Martinez-Palacios, C.A., Vanegas-Perez, R.C. \& Ross, L.G. 2005. The Combined Effect of Salinity and Temperature on the Oxygen Consumption of Juvenile Shrimps Litopenaeus stylirostris. Aquaculture. 244:341 348. doi: 10.1016/j.aquaculture.2004.11.023. 